J. Lake Sci. (湖泊科学), 2015, 27(4): 649-656

DOI $10.18307 / 2015.0413$

(c) 2015 by Journal of Lake Sciences

\title{
江苏滆湖北部区整治后浮游植物时空分布及环境因子变化规律
}

\author{
高 亚 ${ }^{1,2,3}$, 潘继征 ${ }^{2 * *}$, 李 勇 ${ }^{1,3}$,何尚卫 ${ }^{1,2,3}$, 吴晓东 ${ }^{2,4}$ \\ ( 1 : 苏州科技学院环境科学与工程学院,苏州 215009) \\ (2: 中国科学院南京地理与湖泊研究所湖泊与环境国家重点实验室, 南京 210008) \\ ( 3 : 江苏省环境科学与工程重点实验室,苏州 215009) \\ (4: 中国科学院大学, 北京 100049)
}

\begin{abstract}
摘 要: 滆湖是我国长江中下游典型的浅水型湖泊, 为了解其治理后浮游植物群落时空分布规律,2013 年 1-12 月对其 北部区浮游植物及环境因子进行调查. 调查期间共检出浮游植物 7 门 43 属 61 种, 春、冬季以栅藻 (Scenedesmus) 和小环藻 (Cyclotella) 为主要优势种属,夏、秋季以微囊藻 (Microcystis) 和颗粒直链藻 (Melosira granulata) 为主要优势种属, 采样期间 浮游植物生物量最高值为 $90.6 \mathrm{mg} / \mathrm{L}$, 出现在 8 月份, 铜绿微囊藻 (Microcystis aeruginosa) 占绝对优势. 浮游植物平均密度 呈现由西向东递减的趋势,植被覆盖区低于敞水区. 环境因子分析表明: 总氮浓度、总磷浓度、水温是影响滆湖北部区浮 游植物密度和生物量的主要因子. 比较相同月份湖区内部菱角芦苇区和未治理的敞水区的平均生物量,菱角区生物量较 敞水区低约 72.7\% 91. 1\%,芦苇区生物量较敞水区低约 $63.9 \% \sim 83.7 \%$. 在 8 、9 月湖区内敞水区暴发水华时菱角区浮 游植物生物量仅为敞水区的 $14.6 \%$, 芦苇区为敞水区的 $30.3 \%$.
\end{abstract}

关键词: 滆湖;浮游植物; 群落结构;时空分布;环境因子

\section{Spatio-temporal distribution of phytoplankton and environmental factors in the north part of Lake Gehu( Jiangsu) after muti-treatment}

GAO Ya ${ }^{1,2,3}$, PAN Jizheng ${ }^{2}$, LI Yong ${ }^{1,3}$, HE Shangwei ${ }^{1,2,3}$ \& WU Xiaodong ${ }^{2,4}$

(1: School of Environmental Science and Engineering, Suzhou University of Science and Technology, Suzhou 215009, P. R. China)

(2: State Key Laboratory of Lake Science and Eenvironment, Nanjing Institute of Geography and Limnology, Chinese Academy of Science, Nanjing 210008, P. R. China)

(3: Key Laboratory of Environmental Science and Engineering of Jiangsu Province, Suzhou 215009, P. R. China)

(4: University of Chinese Academy of Sciences, Beijing 100049, P. R. China)

Abstract: Lake Gehu is a representative shallow lake located in the downstream of Yangtze River in China. To identify the phytoplankton community distribution after its treatment, a survey was conducted on the phytoplanktonic community and environmental factors in its north part from January to December in 2013. According to the survey, there were altogether seven phylum, fourtythree genus and sixty-one species of phytoplankton, mainly with Scenedesmus and Cyclotella in spring and winter, Microcystis and Melosira granulata in summer and autumn. The maximum phytoplankton biomass during sampling period was 90.6 mg/L in August, mainly with Microcystis aeruginosa. The average density of phytoplankton showed a decreasing trend from west to east, with lower vegetation coverage in the open water area. The environmental factor analysis indicated that total nitrogen, total phosphorus and water temperature were key factors that influence the phytoplanktonic density and biomass in this area. Comparing with the average biomass in the water chestnut area and reed area with that in the untreated open water area in the same month, we found that the water chestnut area decreased with the range of 72.7\%-91.1\% , and 63.9\%-83.7\% in the reed area. In August and September when algal bloom occurred in the open water area, the biomass in the chestnut area and in the reed area was only $14.6 \%$

* 国家水体污染控制与治理科技重大专项 (2012ZX07101-007) 和江苏高校水处理技术与材料协同创新中心项目联 合资助. 2014-07-17 收稿;2014-11-06 收修改稿. 高亚(1990 ), 男, 硕士研究生;E-mail:417671034@ qq. com.

** 通信作者;E-mail: jzhpan@ niglas. ac. cn. 
and $30.3 \%$ of that in the water area, respectively.

Keywords: Lake Gehu; phytoplankton; community structure; spatial and temporal distribution; environmental factors

浮游植物作为湖泊水体中主要的初级生产者, 是食物链的基础环节, 其具有个体小、细胞结构简单、对 栖息环境变化敏感等特点,易受环境中各种因素的影响而在较短的时间内发生变化,相对于其他生物类群 更能及时反映水域生态系统的情况 ${ }^{[1-2]}$, 因此可以通过研究浮游植物的种类、生物量和群落结构等特征, 分 析和评价水质状况 ${ }^{[3-4]}$, 在湖泊治理工作中具有重要的理论和实际意义.

滆湖 $\left(31^{\circ} 35^{\prime} \mathrm{N}, 119^{\circ} 48^{\prime} \mathrm{E}\right)$ 为太湖上游水系, 1998 年以前全湖有 $90 \%$ 以上覆盖着良好的水生植被, 湖泊 具有较强的水体自净能力. 近十多年以来, 随着滆湖周围地区工农业生产的迅速发展和城市化进程的加快, 进入滆湖的工业废水和生活污水不断增加, 兼之湖内人工围网养殖面积逐年扩大, 养殖投㙁带人湖体内的 氮、磷等营养物质逐年增多, 致使湖区水体富营养化程度日益加重, 湖泊生态系统日趋脆弱. 1999 年夏季持 续时间较长的洪水高水位导致滆湖水生植被大面积消失, 至 2009 年 5 月调查为止全湖沉水植被已基本消 亡, 北部湖区尤为严重,水质为劣 $\mathrm{V}$ 类,生态系统已退化到十分严峻的程度.

2010 年有关部门针对滆湖生态系统退化和水质富营养化问题在北部湖区开展了大规模的整治工作, 整治措施主要包括: 前置库人湖污染负荷控制 ${ }^{[5]}$ 、底泥疏浚、大型仿生式机械捞藻和水生植被重建等. 水 生植被重建作为生态修复的主要手段已经被用于国内外各大湖泊的治理 ${ }^{[6]}$, 吴晓东等 ${ }^{[7]}$ 已经对滆湖东岸 生态修复取得的水质净化效果作了相关研究, 而本研究则从水生植被重建后浮游植物群落时空分布规律 出发, 利用水质理化参数和浮游植物多样性分析为工具, 评价治理效果, 为目前国内的浅水湖泊生态修复 工作提供参考.

\section{1 研究方法}

\section{1 样点的布设}

水生植被重建的分布见图 1 , 本研究在滆湖北部敞水区域共设置 6 个采样点, 在水生植被覆盖区设置 3 个采样点 (荷花、芦苇、菱角覆盖区域各设置 1 个采样点). 采样时间为 2013 年 $1-12$ 月,每月 1 次.

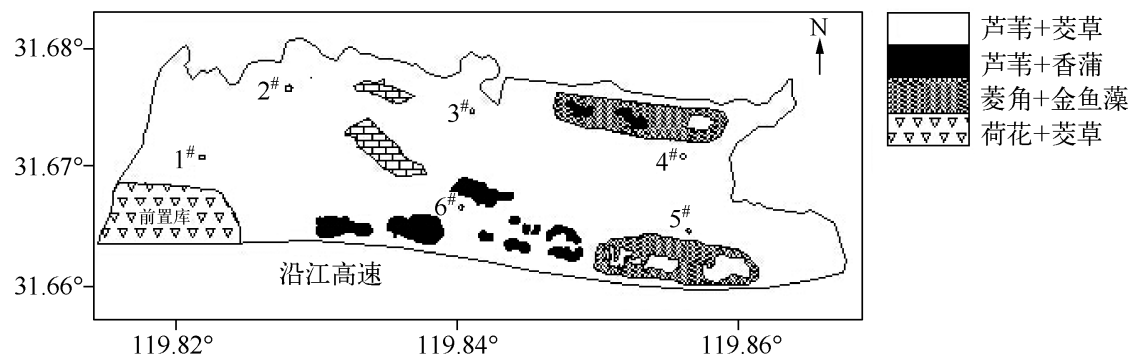

图 1 滆湖北部区采样点

Fig. 1 Sampling sites in the north part of Lake Gehu

\section{2 样品采集与分析}

浮游植物鉴定方法: 在水下 $0.5 \mathrm{~m}$ 处取 $1 \mathrm{~L}$ 水样, 立刻加人 $15 \mathrm{ml}$ 鲁哥试剂固定浮游植物, 带回实验室 静置 $48 \mathrm{~h}$ 后浓缩至 $30 \mathrm{ml}$. 镜检时随机取 $0.1 \mathrm{ml}$ 浓缩样品加到 $40 \mathrm{~mm} \times 40 \mathrm{~mm}$ 计数框内进行浮游植物种类 和密度的鉴定, 每个样品计数 2 次取平均值. 鉴定参照 《中国淡水藻志 $~^{[8]}$ 、 《淡水浮游生物图谱》 ${ }^{[9]}$ 和《中国 淡水生物图谱》 ${ }^{[10]}$.

水温、透明度、 $\mathrm{pH}$ 、溶解氧用仪器现场测定, 总氮 $(\mathrm{TN})$ 、总磷 $(\mathrm{TP})$ 、溶解性总氮 $(\mathrm{TDN})$ 、溶解性总磷 (TDP) 和高锰酸盐指数等理化因子的测定参照 《水和废水监测分析方法 $\rangle^{[11]}$.

\section{3 数据处理}

运用 Margalef 丰富度指数 $(D) 、$ Shannon-Wiener 多样性指数 $\left(H^{\prime}\right) 、$ Pielou 均匀度指数 $(J)$ 描述浮游植物 
群落特征 $^{[12-13]}$, 计算公式分别为:

$$
\begin{gathered}
D=(S-1) / \ln N \\
H^{\prime}=-\sum_{i=1}^{s} p_{i} \ln p_{i} \\
J=H^{\prime} / \ln S \\
Y=\frac{n_{i}}{N} f
\end{gathered}
$$

式中, $p_{i}=n_{i} / N ; p_{i}$ 为第 $i$ 种藻类的个数与样品中所有藻类个数的比值; $n_{i}$ 为第 $i$ 种藻类的个数; $N$ 为所有藻类 总个数; $S$ 为样品中藻类种类数; $f_{i}$ 为第 $i$ 种藻类在各站位出现的频率; $Y$ 为优势度, 并将 $Y>0.02$ 作为优 势种.

数据分析采用 Excel 2003 和 SPSS 17.0 软件,作图采用 Excel 2003 和 Origin 7.5 软件.

\section{2 结果与分析}

\section{1 浮游植物群落组成}

2013 年 1- 12 月滆湖北部共鉴定出浮游植物 7 门 43 属 69 种,各门类种数和密度见表 1 . 其中,绿藻门

\begin{tabular}{|c|c|c|c|c|}
\hline 门类 & 种数 & 种数比例 $/ \%$ & 密度范围 $/\left(\times 10^{4}\right.$ cells $\left./ \mathrm{L}\right)$ & 主要优势种 \\
\hline 蓝藻门 & 14 & 20.3 & $6.73 \sim 91519.00$ & $\begin{array}{l}\text { 铜绿微囊藻 (Microcystis aeruginosa) 、水华微囊藻 ( Micro- } \\
\text { cystis flos-aquae)、鱼腥藻( Anabaena sp.) }\end{array}$ \\
\hline 绿藻门 & 30 & 43.5 & $33.40 \sim 488.50$ & 四尾栅藻 (Scenedesmus quadricauda) \\
\hline 硅藻门 & 15 & 21.7 & $13.90 \sim 578.50$ & 小环藻 (Cyclotella sp.) 、颗粒直链藻( Melosira granulata) \\
\hline 甲藻门 & 3 & 4.3 & $0 \sim 15.09$ & - \\
\hline 裸藻门 & 4 & 5.8 & $0 \sim 37.73$ & - \\
\hline 隐藻门 & 2 & 2.9 & $0 \sim 503.52$ & - \\
\hline 金藻门 & 1 & 1.5 & $0 \sim 8.42$ & - \\
\hline 总计 & 69 & 100 & - & - \\
\hline
\end{tabular}
最多, 占 $43.5 \%$,其次是硅藻门和蓝藻门,分别占 $21.7 \%$ 和 $20.3 \%$.

\section{表 1 滆湖北部区浮游植物种数、密度及优势种}

Tab. 1 Specie numbers, density and dominant species of phytoplankton in the north part of Lake Gehu

\section{2 优势种}

滆湖北部 2013 年 1- 12 月浮游植物优势种见表 2 , 春、冬季节硅藻占绝对优势, 主要优势种为小环藻和 针杆藻 (Synedra sp. ) , 出现频率接近 100\%, 夏季微囊藻占绝对优势, 各点位出现的频率均为 $100 \%$, 最高密 度出现在 8 月份的 $1^{\#}$ 采样点, 为 $91425 \times 10^{4} \mathrm{cell} / \mathrm{s} / \mathrm{L}$. 颗粒直链藻 (多为变种) 在夏季也有出现, 但密度和出现 频率低于微囊藻. 冬季平裂藻 (Merismopedia sp.) 、四角藻 (Tetraedron sp.) 占一定优势, 平均密度分别为 $127.4 \times 10^{4} \mathrm{cell} / \mathrm{s} / \mathrm{L}$ 和 $376.2 \times 10^{4} \mathrm{cell} / \mathrm{s} / \mathrm{L}$, 小环藻在各样点均有出现,但密度低于上述 2 种优势种.

\section{3 不同湖区生物量周年变化}

生物量在滆湖北部不同湖区和不同月份之间均有显著差异 (图 2), 敞水区域生物量平均值普遍高于芦 苇和菱角种植区域,夏季水华暴发时生物量突增达到全年的最高值 $(90.6 \mathrm{mg} / \mathrm{L})$, 此后生物量迅速回落. 芦 苇和菱角种植区生物量走势较为平缓,虽然在夏季有小规模暴发的趋势,但在全年始终低于敞水区.

\section{4 不同湖区 TN、TP 浓度周年变化}

2013 年 1-12 月滆湖北部区不同区域 TN 浓度变化范围为 $0.07 \sim 5.96 \mathrm{mg} / \mathrm{L}$, 平均值为 $2.21 \mathrm{mg} / \mathrm{L} ; \mathrm{TP}$ 浓度变化范围为 $0.03 \sim 0.38 \mathrm{mg} / \mathrm{L}$, 平均值为 $0.09 \mathrm{mg} / \mathrm{L}$, 两者浓度变化趋势类似 ( $\mathrm{TN}$ 、 $\mathrm{TP}$ 浓度为原水测定数 据) (图 3). 原因为在冬季水生植物枯萎无法对水体中的氮、磷起吸收作用, 同时浮游植物受到温度的限制 生物量低, 对氮、磷的消耗少, 经过整个冬季人湖污染物的积累到 4 月份左右氮、磷浓度达到最高值. 而随着 
春、夏季节的来临, 水生植物和浮游植物的复苏导致吸收作用和消耗作用增强, 水体中氮、磷浓度迅速下降, $\mathrm{TN}$ 浓度在 8 月达到最低值, 菱角区 TP 浓度在 9 月达到最低. 根据国家地表水等级的划分标准, TN 浓度处于 劣 $\mathrm{V}$ 类水标准(菱角区处于 $\mathrm{V}$ 类水标准), $\mathrm{TP}$ 浓度基本处于 III 类水标准, 北部区水质富营养化情况仍然十分 严重但治理效果已逐步显现.

表 22013 年滆湖北部区浮游植物优势种属、出现频率及平均密度

Tab. 2 The dominant species, the frequency and average density of phytoplankton in the north part of Lake Gehu in 2013

\begin{tabular}{|c|c|c|c|}
\hline 月份 & 优势种属 & 出现频率/\% & 平均密度 $/\left(\times 10^{4}\right.$ cells $\left./ \mathrm{L}\right)$ \\
\hline \multirow[t]{2}{*}{1} & 小环藻 & 100 & 65.3 \\
\hline & 针杆藻 & 88.6 & 22.6 \\
\hline \multirow[t]{2}{*}{2} & 小环藻 & 100 & 71.5 \\
\hline & 针杆藻 & 100 & 19.6 \\
\hline \multirow[t]{3}{*}{3} & 小环藻 & 100 & 75.9 \\
\hline & 针杆藻 & 100 & 23.5 \\
\hline & 纤维藻 & 88.9 & 22.1 \\
\hline \multirow[t]{2}{*}{4} & 颗粒直链藻 & 100 & 26.9 \\
\hline & 四尾柵藻 & 83.3 & 48.4 \\
\hline \multirow[t]{3}{*}{5} & 四尾栅藻 & 83.3 & 81.2 \\
\hline & 小环藻 & 100 & 145.8 \\
\hline & 颗粒直链藻 & 100 & 42.8 \\
\hline \multirow[t]{2}{*}{7} & 微囊藻属 (主要为铜绿微囊藻、水华微囊藻) & 100 & 15636.5 \\
\hline & 颗粒直链藻 & 100 & 295.4 \\
\hline \multirow[t]{2}{*}{8} & 微囊藻属 (主要为铜绿微囊藻、水华微囊藻) & 100 & 37014.2 \\
\hline & 颗粒直链藻 & 100 & 661.5 \\
\hline \multirow[t]{2}{*}{9} & 微囊藻属 (主要为铜绿微囊藻、水华微囊藻) & 100 & 1814.5 \\
\hline & 颗粒直链藻 & 100 & 2514.3 \\
\hline \multirow[t]{2}{*}{10} & 微囊藻属 (主要为铜绿微囊藻、水华微囊藻) & 83.3 & 498.5 \\
\hline & 平裂藻 & 66.7 & 127.4 \\
\hline \multirow[t]{2}{*}{11} & 四尾栅藻 & 50 & 17.3 \\
\hline & 四角藻 & 66.7 & 376.2 \\
\hline 12 & 小环藻 & 100 & 1008.3 \\
\hline
\end{tabular}

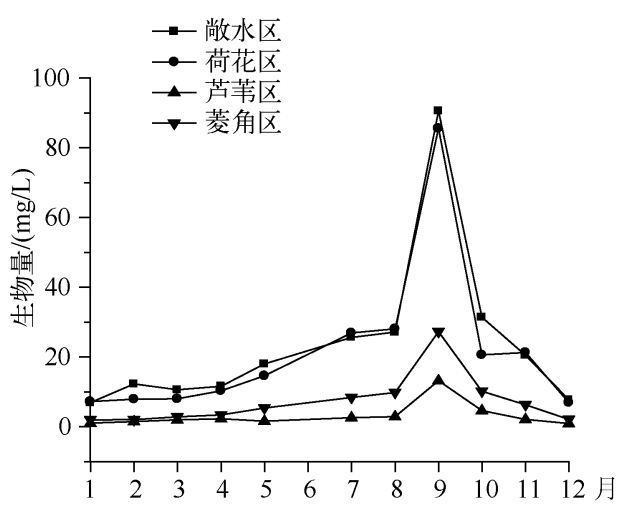

图 2 滆湖北部不同湖区浮游植物生物量周年变化

Fig. 2 Biomass variation of phytoplankton in different lake areas in the north part of Lake Gehu

\section{5 浮游植物多样性指数全年变化}

滆湖北部湖区多样性指数具有明显的季节性变 化 (图 4), 春季适当的气温和丰富的营养盐适宜多数 藻类的生长, 因此多样性指数较高. 随着气温的变化 以及夏季人湖污染物的增加, 一些藻类在竞争中逐 渐成为优势种, 如铜绿微囊藻 $(8$ 月份气温平均值在 $35^{\circ} \mathrm{C}$ 以上, 恰处在铜绿微囊藻生长的最适宜温度范 围内). 铜绿微囊藻在生长中与其他藻类共同竞争营 养源并且释放化学物质抑制其他藻类的生长 ${ }^{[14]}$, 导 致整体湖区多样性指数下降, 在 8 月份水华暴发最严 重时多样性指数降至最低, 而到了秋季气温回落, 微 囊藻失去最适宜的生长条件, 绿藻硅藻失去微囊藻 的抑制作用从而生物量增加, 多样性指数开始缓慢 上升, 藻类生态系统慢慢恢复. 

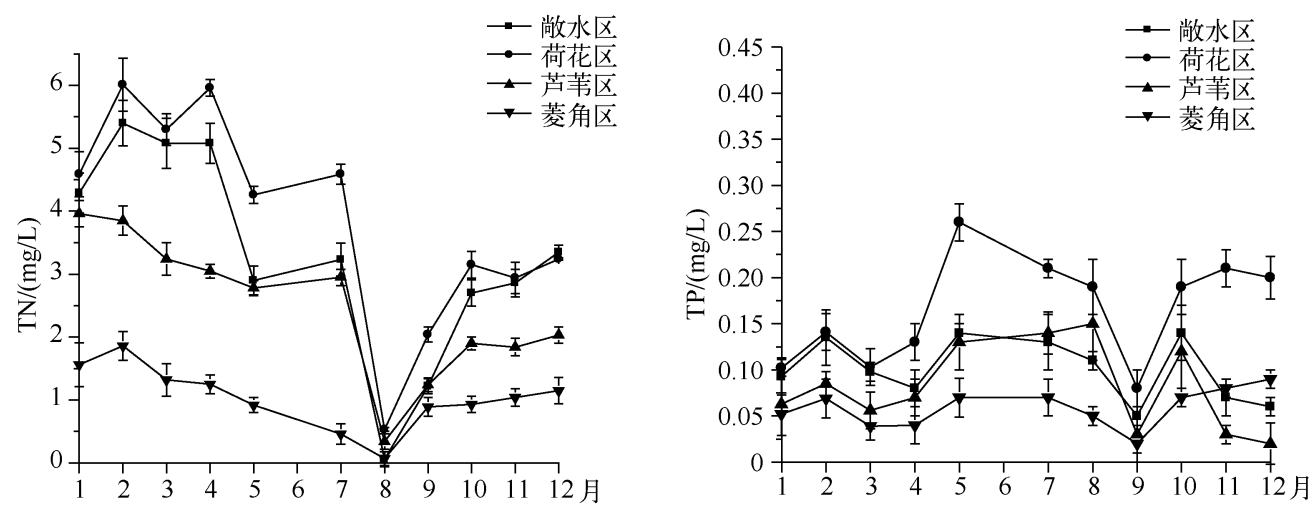

图 3 滆湖北部不同湖区 TN、TP 浓度的周年变化

Fig. 3 Annual changes of TN and TP concentrations in different lake areas in the north part of Lake Gehu

在湖区内部的 Shannon-Wiener 多样性指数 $\left(H^{\prime}\right) 、$ Margalef 丰富度指数 $(D)$ 值存在明显差异 (表 3 ), $H^{\prime}$ 在有水生 植被种植的区域要明显高于其他敞水区域, 同时水体中浮 游植物生物量较低, 藻种以硅藻为主, 表明这些区域水体较 为清洁, 生态系统优于敞水区. Pielou 均匀度指数 $(J)$ 变化 趋势较为平缓, 各月份之间差异不明显. 一般说来, $H^{\prime}$ 值 越大, 水质越好. $H^{\prime}$ 处于 $0 \sim 1$ 时, 表示重度污染; $H^{\prime}$ 值为 $1 \sim 3$ 时, 表示中度污染; 而 $H^{\prime}$ 值大于 3 时, 表示无污染. 从多样性指数分析来看, 滆湖北部区夏季为重度污染, 春、秋、冬季为中度污染. $J$ 在 $0 \sim 0.3$ 之间为重度污染, 在 $0.3 \sim 0.5$ 之间为中度污染, 而在 $0.5 \sim 0.8$ 之间为轻 度污染, 由此可见北部区夏季为中度污染, 春、秋、冬季 为轻度污染.

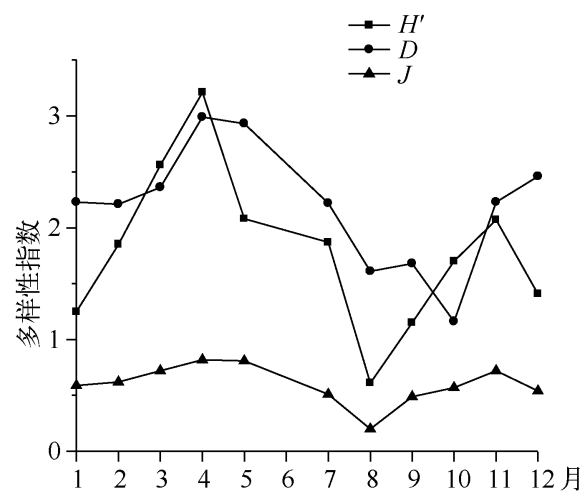

图 4 滆湖北部区浮游植物多样性指数季节变化 Fig. 4 Seasonal changes of phytoplankton diversity indexes in the north part of Lake Gehu

表 32013 年 5 月滆湖北部区浮游植物多样性指数

Tab. 3 The phytoplankton diversity indexes in the north part of Lake Gehu in May, 2013

\begin{tabular}{cccccccccc}
\hline 多样性指数 & $1^{\#}$ & $2^{\#}$ & $3^{\#}$ & $4^{\#}$ & $5^{\#}$ & $6^{\#}$ & 荷花区 & 芦苇区 & 菱角区 \\
\hline$H^{\prime}$ & 2.35 & 2.28 & 2.20 & 1.89 & 1.90 & 1.84 & 2.61 & 2.67 & 2.2 \\
$D$ & 3.90 & 3.70 & 2.64 & 2.34 & 2.60 & 2.40 & 3.49 & 2.86 & 3.08 \\
$J$ & 0.76 & 0.73 & 0.89 & 0.91 & 0.79 & 0.80 & 0.87 & 0.91 & 0.89 \\
\hline
\end{tabular}

\section{6 浮游植物与环境因子的关系}

水体理化因子对浮游植物的生长有着直接或者间接的作用 ${ }^{[15-16]}$. Pearson 相关性分析表明 (表 4): 浮游 植物密度与水温、TDN 浓度、pH 值等因子存在极显著正相关 $(P<0.01)$, 与 $\mathrm{TP}$ 浓度存在显著正相关 $(P<0.05)$, 水温和 TN、TDN 浓度之间也存在显著相关性.

\section{3 讨论}

\section{1 植被修复对浮游植物生态结构的影响}

滆湖北部区浮游植物季节变化差异显著, 春、冬季优势种以绿藻门和硅藻门为主, 夏、秋季以蓝藻门为 主, 与陈立婧等 ${ }^{[17]}$ 的调查结果基本一致. 通过与 2009-2010 年数据 ${ }^{11}$ 对比后发现,治理后北部区浮游植物种

(1)“十一五”国家水体污染与治理科技重大专项湖泊主题太滆项目太滆课题子课题(2008ZX07101-007-05). 
类总数上升约 $40 \%$, 分布的门类更加广泛, 从原来的 5 门增加到 7 门. 2010 年 8 月优势种有 4 种, 分别为铜 绿微囊藻、微小平裂藻、点状平裂藻和小球藻, 至 2013 年 8 月优势种变为铜绿微囊藻、密集微囊藻、水华微囊 藻、颗粒直链藻. 研究表明未受污染的水体中浮游植物的种类多, 主要是硅藻门, 少数为绿藻门和蓝藻门. 而 当水体受到污染之后, 浮游植物群落的种类以硅藻门占优势改变为以蓝藻门、绿藻门占优势 ${ }^{[18]}$.

表 4 滆湖北部区浮游植物密度与环境因子的 Pearson 相关系数

Tab. 4 Pearson correlations between phytoplankton density and environmental factors in the north part of Lake Gehu

\begin{tabular}{cccccccc}
\hline 环境因子 & 浮游植物密度 & $\mathrm{pH}$ & 水温 & $\mathrm{TN}$ & $\mathrm{TDN}$ & $\mathrm{TP}$ & $\mathrm{TDP}$ \\
\hline 浮游植物密度 & 1.000 & - & - & - & - & - & - \\
$\mathrm{pH}$ & $0.635^{* *}$ & 1.000 & - & - & - & - & - \\
水温 & $0.593^{* *}$ & 0.360 & 1.000 & - & - & - & - \\
$\mathrm{TN}$ & $-0.670^{*}$ & -0.429 & $-0.646^{*}$ & 1.000 & - & - & - \\
$\mathrm{TDN}$ & $0.218^{* *}$ & -0.551 & $-0.684^{*}$ & $0.962^{* *}$ & 1.000 & - & - \\
$\mathrm{TP}$ & $0.218^{* *}$ & -0.458 & 0.424 & -0.055 & 0.068 & 1.000 & - \\
$\mathrm{TDP}$ & 0.195 & -0.432 & 0.143 & 0.036 & 0.177 & $0.912^{* *}$ & 1.000 \\
\hline
\end{tabular}

*表示显著相关, $P<0.05 ; * *$ 表示极显著相关,$P<0.01$.

滆湖北部区浮游植物生物量总体呈现由西北向东南递减的趋势, 与污染物的流向基本一致, 结果表明 位于滆湖的前置库人湖河口附近的 $1^{\#}$ 点、 $2^{\#}$ 点和荷花种植区浮游植物生物量明显高于其他区域, 优势种主 要为硅藻门( 小环藻等), 一些研究表明硅藻由于其自身沉降系数较高的缘故, 需要生活在较急的水流中以 保持在水体中悬浮的状态从而利用阳光进行光合作用 ${ }^{[19]}$, 而硅藻的大量繁殖会对水体中生物量的增加贡献 很大. 从水质分析的数据表明这些区域营养盐浓度高, 水深较浅有利于藻类的光合作用从而导致生物量增 加. 而随着污染物进入湖区, 水生植物的净化降低了水体的氮、磷等营养物质浓度, 通过竞争作用抑制了藻 类的生长. 研究表明湖区内部生物量平均值约为人湖口处的 $27 \%$ 左右, 整治区内部浮游植物量得到有效的 控制.

比较相同月份湖区内部菱角区、芦苇区和未治理敞水区的生物量均值发现, 菱角区生物量较敞水区低 约 72. 7\% 91. 1\%, 芦苇区生物量较敞水区低约 63.9\% 83.7\%（图 2). 在 $8 、 9$ 月湖区内敞水区暴发水华 时, 菱角和芦苇有效控制区域内浮游植物的生物量, 避免水华的发生, 菱角区浮游植物生物量仅为敞水区的 $14.6 \%$,芦苇区为敞水区的 $30.3 \%$.

通过对全年不同湖区多样性指数的分析发现: 不同植被的种植以及处于不同营养盐浓度下多样性指数 存在一定的规律性 (表 3) : (1) 人湖河口内的荷花种植区内 $H^{\prime}$ 值最高, 此处营养盐浓度为全湖最高、水流湍 急, 适宜硅藻和绿藻大量繁殖, 藻种丰富多样. 相比较而言, 位于湖区最东端与滆湖南部相连的芦苇菱角混 生区, 其营养盐经过全湖湖水的稀释之后只有人湖河口的 $80 \%$ 左右, 水流常年处于静止状态, 并且芦苇由于 其种植密集及植株较荷花高, 对阳光的遮蔽作用更强, 限制了浮游植物的光合作用. 因此在营养盐浓度低、 光合作用受限制和不利的水利条件下只有少数浮游植物能正常生长, 导致东部浮游植物多样性常年处于低 水平. (2) 在水利条件更好、阳光充足、营养盐高的水域有利于更多的浮游植物生长. 但是同样处于人湖河 口处敞水区的 $D$ 值高于荷花种植区, 研究表明荷花可以通过影响浮游植物对光照和营养盐的利用达到限制 其生长的目的 ${ }^{[20]}$. (3) $J$ 值在全湖范围内差异不明显, 因此可根据其计算公式中与 $H^{\prime}$ 呈正比、与浮游植物种 类呈反比的特点比较出不同湖区对浮游植物的影响效果, 即芦苇区 $>$ 菱角区 $>$ 荷花区 $>$ 敞水区.

对比 2009 年(1)北部区多样性指数发现 (表 5 ), 治理后湖区内多样性指数均有提升, $H^{\prime}$ 敞水区增加 $9.4 \%$, 植被区增加 $35.9 \% ; D$ 敞水区增加 $14.6 \%$, 植被区增加 $40.9 \% ; J$ 敞水区增加 $19.6 \%$, 植被区增加 $32.6 \% . H^{\prime}$ 和 $D$ 分析表明湖区水体环境得到改善, 能够生长的浮游植物种类增加, 分布也更加均匀.

(1) “十一五” 国家水体污染与治理科技重大专项湖泊主题太滆项目太滆课题子课题(2008ZX07101-007-05). 
表 52009 年和 2013 年滆湖北部区浮游植物多样性指数比较

Tab. 5 Comparison of phytoplankton diversity indexes in the north part of Lake Gehu between 2009 and 2013

\begin{tabular}{cccc}
\hline 多样性指数 & 2009 年北部区 & 2013 年北部敞水区 & 2013 年北部植被区 \\
\hline$H^{\prime}$ & 1.655 & 1.81 & 2.25 \\
$D$ & 1.98 & 2.27 & 2.79 \\
$J$ & 0.46 & 0.55 & 0.61 \\
\hline
\end{tabular}

\section{2 植被修复对水体氮、磷的影响}

滆湖北部区水体中氮、磷浓度与上游来水中氮、磷浓度和湖区本身的净化效果有密切关系, 限于人湖污 染物控制能力有限, 湖区内部的消耗成为降低水体中氮、磷浓度的主要手段. 水生植物对水体中氮、磷等营 养盐具有吸收作用, 并以此影响浮游植物的群落分布, 高吉喜等对滇池的研究表明, 菱角等水生植被的种植 能有效提高对氮、磷的净化效果 ${ }^{[21]}$. 分析表明从敞水区到内部菱角覆盖区氮、磷浓度有递减的趋势,菱角种 植区 TN 浓度比外围敞水区下降 $68.9 \%$, TP 浓度下降 $49.6 \%$, 菱角种植区内氮、磷含量远远低于未种植区, 并且种植区域内水体透明度显著提高 $(P<0.05)$, 藻类密度明显下降,多样性指数增大, 证实了芦苇、菱角的 种植在滆湖水质净化和生态恢复工作中取得很好的效果. 但是研究发现种植荷花的区域 TN TP 浓度却异常 增高, 这与以往研究中提到的荷花种植能削减水体中氮、磷营养盐不符 ${ }^{[22]}$, 分析可能的原因为荷花的种植区 位于北部区污染物人湖口处, 其水体中本底营养盐浓度较高, 而水生植物对氮、磷吸收能力有限, 所以造成 此处浓度较高.

对比 2009 年北部区全年氮、磷浓度平均值 (1)发现: 敞水区 TN 浓度下降 $36.1 \%$, TP 浓度下降 $59.9 \%$; 植 被覆盖区 TN 浓度下降 $68.9 \%$, TP 浓度下降 71.2\%（表6),处理效果显著.

表 62009 年和 2013 年滆湖北部区氮、磷浓度比较

Tab. 6 Comparison of nitrogen and phosphorus concentrations between 2009 and 2013 in the north part of Lake Gehu

\begin{tabular}{llll}
\hline 营养盐指标 & $2009-2010$ 年 & 2013 年敞水区 & 2013 年植被覆盖区 \\
\hline $\mathrm{TN} /(\mathrm{mg} / \mathrm{L})$ & 4.19 (劣 $\mathrm{V}$ 类 $)$ & 3.24 (劣 $\mathrm{V}$ 类 $)$ & $2.94($ 劣 $\mathrm{V}$ 类 $)$ \\
$\mathrm{TP} /(\mathrm{mg} / \mathrm{L})$ & $0.24($ 劣 $\mathrm{V}$ 类 $)$ & $0.14($ III 类 $)$ & $0.08($ II 类 $)$ \\
\hline
\end{tabular}

\section{4 结论}

1) 通过对滆湖北部区浮游植物组成的分析发现, 北部区浮游植物种类繁多, 季节性差异明显, 种类主要 集中在蓝藻门、绿藻门、硅藻门. 绿藻门在全年均占有较大比重, 出现频率为 $100 \%$. 2013 年生物量小于 2009 年,有水生植被区小于无植被区, 湖区内部小于人湖河口. 物种多样性分析表明, 水生植被的种植影响水体 中营养盐浓度、水力和光合条件, 进而改变了原有的浮游植物生态结构, 无植被覆盖区浮游植物种类多, 容 易发生水华.

2) 北部区综合整治改变了湖区内部的环境因子,水体中营养盐浓度由人湖河口处向东南角递减,为不 同营养盐需求的植物提供了适宜的生长条件, 因此 2013 年湖区内部多样性指数较 2009 年有较大提高. 前置 库人湖污染控制也有利于降低湖区内氮、磷浓度, 减轻湖区内部净化措施负荷, 是整治工作的重要方面.

3) 纵观 3 种植被对生态修复的影响: 荷花的生长对水位要求高,较深的水位不利于荷花的生长,所以只 能种植在北部湖区水位较浅的人湖河口处,而此处污染物负荷较高超出其净化能力,因此荷花无法在修复 工作得到有效利用. 而芦苇和菱角种植在内湖区域,且湖中的水力适合两者的生长,对水质的净化效果要优 与荷花. 出于保证植被多样性的考虑建议两者混合种植并增大种植面积. 另外, 芦苇和菱角是很好的经济作

(1) “十一五” 国家水体污染与治理科技重大专项湖泊主题太滆项目太滆课题子课题(2008ZX07101-007-05). 
物, 适当加以利用可以提高当地居民收人.

\section{5 参考文献}

[1] 刘 静,杜桂森, 刘晓瑞等. 密云水库的浮游生物群落. 西北植物学报,2004,24(8): 1485-1488.

[ 2 ] Perez JR, Loureiro S, Menezes S et al. Assessment of water quality in the Alqueva Reservior (Portugal) using bioassays. Environmental Science and Pollution Research,2010,17(3):688-702.

[ 3 ] Yang YS, Wang L. A review of modeling tools for implementation of the EU water framework directive in handing diffuse water pollution. Water Resources Management, 2010, 24(9):1819-1843.

[4] 况琪军, 马沛明, 胡征宇等. 湖泊富营养化的藻类生物学评价与治理研究进展. 安全与环境学报, 2005, 5 (2): $87-91$.

[ 5 ] 张毅敏,段金程,昆建顷等. 河口前置库系统在滆湖富营养化控制中的应用研究. 生态与农村环境学报,2013,29 (3) :273-277.

[6] Covneny MF, Stites DL. Nutrient removal from eutrophic lake water by wetland filtration. Ecological Engineering, 2002, 19:141-159.

[ 7 ] 吴晓东, 潘继征, 李文朝等. 滆湖东岸生态修复试验区的水质净化效果. 生态与农村环境学报, 2013,29(3): 284-289.

[8] 黎尚豪, 毕列爵. 中国淡水藻志. 北京:科学出版社, 1998 .

[9] 山东省水产学校. 淡水浮游生物图谱. 烟台: 山东省水产学校, 1976.

[10］韩茂森,束蕴芳. 中国淡水生物图谱. 北京:海洋出版社,1955.

[11] 国家环境保护总局《水和废水监测分析方法》编委会. 水和废水监测分析方法: 第 4 版. 北京: 中国环境科学出版 社, 2002 .

[12] Belaoussoff S, Kevan PG, Murphy S et al. Assessing tillage disturbance on assemblages of ground beetles (Coleoptera: carabidae) by using a rang of ecological indices. Biodiversity and Conservation, 2003, 12 (5) : 851-882.

[13] Lampitt RS, Wishner KF, Turley CM et al. Marine snow studies in the northeast Atlantic: distribution, composition and roles as a food source for migrating plankton. Marine Biology, 1993,116:687-702.

[14] 史红星,曲久辉, 刘会娟等. 微囊藻毒素产生过程中氮素作用的同位素示踪研究. 科学通报, 2008,53:407-412.

[15] 王书航,姜 霞,钟立香等. 巢湖沉积物不同形态氮季节性赋存特征. 环境科学,2010,31(4):946-953.

[16] Reynold CS. Growth and buoyancy of Microcystis aeruginosa Kutz emend. Elenkin in a shallow eutrophic lake. Proceedings of the Royal Society B ,Biological Sciences, $1973, \mathbf{1 8 4}: 29-50$.

[17] 陈立婧,彭自然, 孔优佳等. 江苏滆湖浮游藻类群落结构特征. 生态学杂志, 2008,27(9):1549-1556.

[18］邓义祥,张爱军.试论藻类在水体污染检测中的运用. 环境与开发,1999,14(1):43-45.

[19］郭蔚华,李 楠,张 智等. 嘉陵江出口段三类水体蓝绿硅藻优势种变化机理. 生态环境学报,2009,18(1):51-56.

[20］何连生,孟繁丽,孟 点等. 利用荷花治理白洋淀水体富营养化的原位围隔研究. 湿地科学, 2013,11(2):282-285.

[21] 高吉喜, 叶 春, 杜 娟等. 水生植物对面源污水净化效率研究. 中国环境科学, 1997,17(3):247-251.

[22] 徐 丹. 再生水调蓄库塘植物群落与水体氮、磷削减关系的研究 [学位论文]. 保定: 华北电力大学, 2012 . 